\title{
Analyzing and comparing the impacts and outcomes of two different types of surgeries - Minimally Invasive Surgeries (MIS) and Conventional Surgeries (CVS) on patients suffering from Degenerative Mitral Valve Diseases
}

\author{
Halim $\mathrm{M}^{1^{*}}$, AlSayegh $\mathrm{M}^{1^{*}}$, Umenne $\mathrm{CA}^{1}$, Vadithya $\mathrm{P}^{1}$, Panicker $\mathrm{SV}^{1}$, Israel $\mathrm{KA}^{1}$, Halim $\mathrm{A}^{2}$ \\ ${ }^{1}$ University of Salford, MSc Biomedical Science, Greater Manchester, United Kingdom \\ ${ }^{2}$ Zhongshan Hospital, Shanghai Medical College of Fudan University, Shanghai, China
}

Corresponding Author(s): Michael Halim and Mariam AlSayegh

Address: University of Salford, MSc Biomedical Science, Greater Manchester, United Kingdom.

Received date: 05 December 2020; Accepted date: 01 February 2021; Published date: 10 February 2021

Citation: Halim M, AlSayegh M, Umenne CA, Vadithya P, Panicker SV, Israel KA, Halim A. Analyzing and comparing the impacts and outcomes of two different types of surgeries - Minimally Invasive Surgeries (MIS) and Conventional Surgeries (CVS) on patients suffering from Degenerative Mitral Valve Diseases. J Health Care and Research. 2021 Feb 10;2(1):17-32.

Copyright (C) 2021 Halim M, AlSayegh M, Umenne CA, Vadithya P, Panicker SV, Israel KA, Halim A. This is an open-access article distributed under the Creative Commons Attribution License, which permits unrestricted use, distribution, and reproduction in any medium, provided the original work is properly cited.

\begin{abstract}
Background: Degenerative Mitral Valve Disease (DMVD) is the most common cause of Mitral Regurgitation (MR) and the main reason for surgical intervention in patients with heart diseases. Traditionally, open-heart surgery or else sternotomy was the main surgical approach used until a few decades ago when Minimally Invasive Surgical (MIS) approaches came into existence. MIS approach is thought to have superior clinical outcomes while minimizing hospital and ICU stay; blood loss translating to fewer blood transfusions, and lower incidence of complications. Despite many promising institutional and regional results of benefits of MIS over the conventional surgery, the adoption of MIS worldwide in Mitral Valve Repair (MVR) has been so poor. There are still arguments on the surgical and clinical benefits of MIS and more importantly the cost and the expertise involved in conducting MIS.

Objective: This study aimed at comparing the costs, clinical and surgical outcomes of MIS with conventional sternotomy MVR surgeries in patients with DMVD.

Methods: Electronic databases such as MEDLINE, PubMed, Science Direct, and Google Scholar were searched for relevant peer-reviewed articles comparing costs and clinical outcomes of MIS with the conventional surgery/sternotomy in DMVD from January 2013 to November 2020. A total of 7 articles were identified as most relevant and therefore included in the meta-analysis.

Results: Findings from the meta-analysis pointed out that repair of the mitral valve using MIS patients with DMVD has benefits such as short ICU, intubation and hospital duration; less loss of blood and therefore less need of blood transfusion; low postoperative infection rates; smaller incisions; early ambulation and return to activities of daily living over conventional surgery while maintaining similar costs of care and clinical outcomes as a sternotomy.

Conclusions: Given the added advantages of MIS in mitral valve surgeries, cardiac surgeons should consider it over the conventional open surgeries in patients with DMVD. In this regard, more surgeons and nurses need
\end{abstract}


Citation: Halim M, AlSayegh M, Umenne CA, Vadithya P, Panicker SV, Israel KA, Halim A. Analyzing and comparing the impacts and outcomes of two different types of surgeries - Minimally Invasive Surgeries (MIS) and Conventional Surgeries (CVS) on patients suffering from Degenerative Mitral Valve Diseases. J Health Care and Research. 2021 Feb 10;2(1):17-32.

Literature Review

to gain competency in conducting MIS through training and fellowships; hospitals need to acquire the needed infrastructure to enable the adoption of MIS.

\section{Keywords}

Degenerative Mitral Valve Disease, Mitral Valve Prolapse Syndrome, Minimally Invasive Surgical Procedures, Mitral Valve Repair, Mini-Thoracotomy, Open Surgery, Open-Heart Surgery, Sternotomy, Conventional Surgery

\section{Background}

Degenerative Mitral Valve Disease (DMVD) also known as mitral valve prolapse syndrome is a most common disorder affecting $2-3 \%$ of people globally and the leading cause of Mitral Regurgitation (MR) in the USA [1-2]. Although its etiology is not well understood, genetic mutations are thought to play a pivotal role in the progressive non-inflammatory changes [3] that occur in the structure of the Mitral Valve (MV) in MVDD [3-4]. When left untreated, DMVD causes cardiomegaly and dysrhythmias like Atrial Fibrillation (AF) that affects the working of the heart and can be fatal [5-6]

For many decades, open-heart surgery through Median Sternotomy (MS) has been used in the repair of insufficient MV. It involves making an 8-10-inch cut through the patient's breastbone under general anesthesia to expose the heart. Cardiopulmonary bypass is done to shunt blood away from the heart to enable the surgeon to operate [7-9]. Despite the surgical advantage of having the operation site fully exposed and thus increasing the efficiency of the procedure, open MV repair or replacement carries increased intraoperative and postoperative risks especially in elderly patients who have other comorbid like diabetes and obesity [10-12].

Similarly, there is increased bleeding, the risk for infection, and disturbed body image due to wound healing complications like scaring as a result of a large incision. Moreover, there is an argument about open surgery being associated with more complications such as stroke, AF, Ventricular Arrhythmias (VA), postoperative ischemia and infarction, cardiac arrest, pleural effusion, pneumonia, thrombocytopenia, need for prolonged intubation, damage to heart, and lung tissues and cardiac arrest [3,13-15]. For patients who might need a reoperation following Mitral Valve Repair (MVR), it becomes challenging for surgeons due to dense adhesions following the healing process from previous surgery with a high risk of damage of the underlying vascular structures [16-18] (Fig-1).

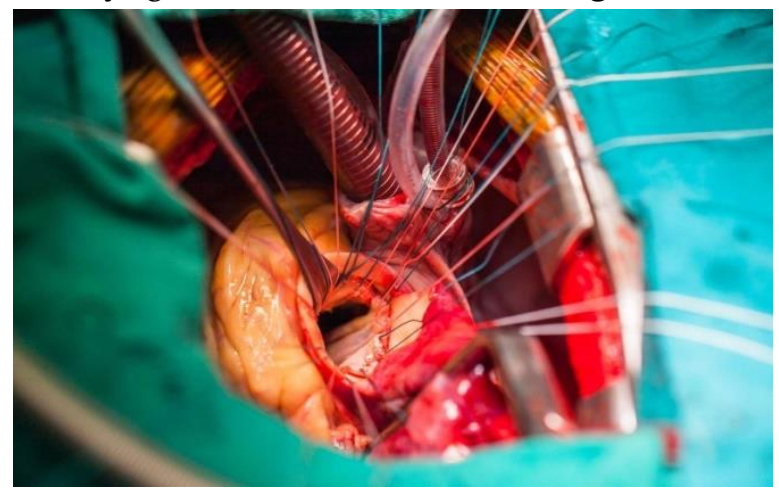

Fig-1: Open heart surgery for Mitral Valve Repair [19]

Following these shortcomings, there has always been a search for a better surgical approach in the management of DMVD. One of the outcomes of such inquest was realized in the mid-199os when we had popularization of the use of Minimally Invasive Surgical (MIS) procedures in patients with DMVD [2023]. MIS involves two techniques: non-robotic or thoracoscopic and robotic. In the first approach, a small incision (2-4-inches) is made on the patient's chest and the surgeon accesses the targeted organ by inserting a small long flexible tube fitted with a video camera- thoracoscope- to the operation site. The surgeon then repairs the defect with long instruments inserted through the tube $[3,24,25]$.

In the second technique, the surgeon works remotely on the heart using robotic arms rather than physical hands. The surgeon observes the heart on a high-definition $3 \mathrm{D}$ video on a monitor and does the operation by manipulating the robotic arms as what he/she would have done using hands in open surgery [26-27]. Usually, we have a team of other doctors, nurses, and anesthesiologists at the patient's bedside for changing the surgical equipment, monitoring patient progress amongst other tasks. The surgical setting in MIS is in a way that can allow open surgery 
Citation: Halim M, AlSayegh M, Umenne CA, Vadithya P, Panicker SV, Israel KA, Halim A. Analyzing and comparing the impacts and outcomes of two different types of surgeries - Minimally Invasive Surgeries (MIS) and Conventional Surgeries (CVS) on patients suffering from Degenerative Mitral Valve Diseases. J Health Care and Research. 2021 Feb 10;2(1):17-32.

\section{Literature Review}

just in case MIS hits obstacles or goes wrong [3,28-29]

(Fig-2).

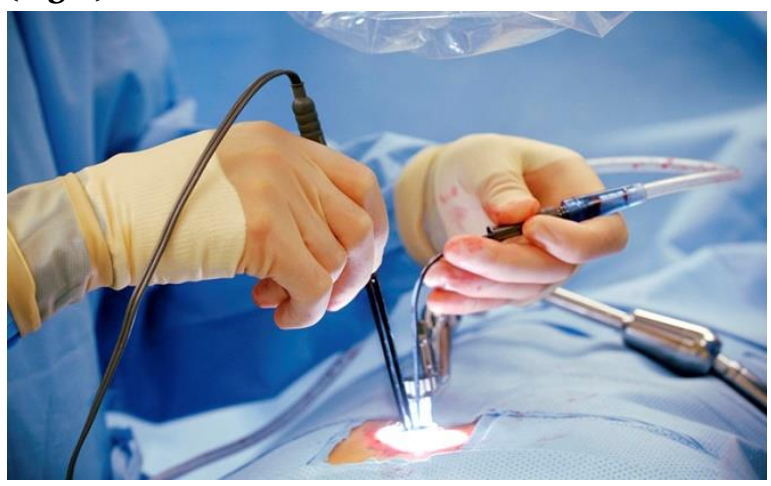

Fig-2: Minimally invasive repair of Mitral Valve in progress [30]

Even though MIS takes a long time especially in the planning and arranging the surgical apparatus and machines and at the same time requires highly expertise training and experience [29-30], some studies have linked MIS to many advantages over conventional open surgeries. They argue that MIS has less loss of blood, low risk for infection, reduced trauma, short hospitalization days, smaller scars, and has high precision especially with the advent in technology enabling machine involvement [26,31-32]. However, inadequate comparable data between Minimally Invasive Mitral Valve Repair (MIMVR) with conventional repair and low clinical evidence has clouded the adoption and roll-out of MIMVR as the golden surgical intervention in DMVD [20,33-34]. As well, there is no consensus as to whether MIS affects the prevention of reoperations and prevention of postoperative complications over open surgeries [35]. This study aims at building strong clinical evidence by comparing MIS versus sternotomy in terms of costs, clinical and surgical outcomes.

\section{Methods}

\section{Database Searches:}

The study applied systematic meta-analysis to review and analyze research studies on the topic. MEDLINE, PubMed, Science Direct, and Google Scholar databases were searched using a systematic computerized literature search system for various peer-reviewed studies comparing clinical outcomes and costs of MIS versus sternotomy published from 2013 to 2020 in English.
The search was done by combining various keywords as well as medical subheadings (Mesh terms). The keywords used in the search included: "minimally invasive surg*", "open surg*”, "open heart surg*", and degenerative mitral valve disease. On the other hand, the Mesh terms used were: minimally invasive surgical procedures, thoracic surgery, and mitral valve prolapse syndrome.

The comparable outcomes used in the search included: clinical outcomes, echocardiographic outcomes, hospitalization stay, intubation duration, postoperative complications, stroke, atrial fibrillation, myocardial infection, mortality and morbidity, ambulation, bleeding time, blood transfusion, cardiopulmonary bypass time, cross-clamp, reoperation, operative, and postoperative costs and postoperative infections $[15,20,36,37]$.

The references to the articles identified were further searched from the databases to identify more articles and. The search was limited to only peer-reviewed articles with full text. The study identified 198 relevant articles.

\section{Article Screening Methods:}

The 198 articles identified were subjected to a screening process which was done by handpicking one by one. Those that lacked an abstract; duplicates; animal subjects; studies with un-matching titles and premium subscribed full-text access were screened out. Skimming through titles and abstracts was done to identify studies that had the keywords identified in this study. A total of 141 articles were screened out.

\section{Inclusion and Exclusion:}

The exclusion criteria included studies with low clinical evidence for example case reports and letters were excluded. Consequently, studies with a high likelihood of selection bias were excluded. For example, retrospective studies that did not attempt to do propensity matching to ensure some uniformity in the two arms; narrative reviews too. Also, studies with less than 100 sample size were not included. Besides, those studies whose titles did not match the study variables and outcome measures were excluded. Time frames were limited to January 2013 to November 
Citation: Halim M, AlSayegh M, Umenne CA, Vadithya P, Panicker SV, Israel KA, Halim A. Analyzing and comparing the impacts and outcomes of two different types of surgeries - Minimally Invasive Surgeries (MIS) and Conventional Surgeries (CVS) on patients suffering from Degenerative Mitral Valve Diseases. J Health Care and Research. 2021 Feb 10;2(1):17-32.

\section{Literature Review}

2020 to get the latest articles.

After this process, 50 articles were excluded. Therefore, only 7 studies that met the inclusion criteria were included in this meta-analysis. The studies included; 2 meta-analyses and 5 retrospective institutional and regional reviews.

\section{Results}

Minimally Invasive Surgery (MIS) Versus Conventional Surgeries in DMVD management in terms of clinical and time-related outcomes:

Due to inadequate data to compare short term, midterm-long-term outcomes and costs between MIS and conventional surgeries, studies have been conducted to fill this gap to provide strong clinical evidence about the benefits that MIS has over open surgery while maintaining similar or better clinical outcomes.

Cao et al. (2013) [20] carried out a desk-review meta-analysis study to compare clinical outcomes of MIMVR versus convention MVR in 1,940 DMVD patients. The study included 7 studies (1- Randomized Clinical Trial (RCT) and 6 retrospective studies) searched from electronic databases from January 1995 to July 2013 meeting a certain inclusion criterion. The study measurement indicators included: incidence of stroke, renal failure, AF, wound infection, Myocardial Infarction (MI); cross-clamp and cardiopulmonary bypass time; mortality rate; readmission rates within 30 days; duration in Intensive Care Unit (ICU) and hospitalization and echocardiographic outcomes in terms of severity of Mitral Regurgitation (MR). The 953 patients who had undergone MIMVR had longer cross-clamp and cardiopulmonary bypass time compared to the 1,011 who had undergone sternotomy. Likewise, the MIVR group spent less duration in the ICU but there were no significant differences in overall hospitalization duration in both groups.

Contrary to findings that MIS has better clinical

Table-1: Showing Perioperative clinical and time-related outcomes of patients who underwent mitral valve repair through a minimally invasive thoracotomy versus conventional sternotomy approach [20]

\begin{tabular}{|c|c|c|c|c|c|c|}
\hline \multirow{2}{*}{$\begin{array}{c}\text { Outcomes } \\
\text { Clinical outcomes }\end{array}$} & \multirow{2}{*}{$\begin{array}{c}\text { Included } \\
\text { studies } \\
\text { No. of } \\
\text { studies }\end{array}$} & \multicolumn{2}{|c|}{ Sample size } & \multicolumn{2}{|c|}{ Overall statistics } & \multirow[b]{2}{*}{$\begin{array}{l}I^{\wedge} 2 \\
(\%)\end{array}$} \\
\hline & & MIMVR (n) & Sternotomy (n) & $\begin{array}{c}\text { Relative Risk } \\
\text { (95\% CI) }\end{array}$ & $P$-value & \\
\hline Mortality & 7 & 952 & 1,011 & $1.23(0.22-6.88)$ & 0.81 & o \\
\hline $\begin{array}{l}\text { Cerebrovascular } \\
\text { accidents* }\end{array}$ & 6 & 906 & 929 & $1.43(0.74-2.76)$ & 0.29 & o \\
\hline Renal failure & 3 & 284 & 305 & $0.96(0.31-3.00)$ & 0.95 & $\mathrm{o}$ \\
\hline Wound infection & 4 & 634 & 670 & $2.97(0.47-18.87)$ & 0.25 & 29 \\
\hline Reoperation for bleeding & 6 & 848 & 896 & $1.25(0.60-2.62)$ & 0.55 & 35 \\
\hline Aortic dissection & 4 & 688 & 724 & $4.84(0.55-42.43)$ & 0.15 & o \\
\hline Myocardial infarction & 3 & 284 & 305 & $1.15(0.24-5.64)$ & 0.86 & o \\
\hline $\begin{array}{l}\text { Readmission within } 30 \\
\text { days }\end{array}$ & 2 & 308 & 315 & $0.61(0.31-1.21)$ & 0.16 & $\mathrm{o}$ \\
\hline $\begin{array}{l}\text { Time-related } \\
\text { outcomes }\end{array}$ & $\begin{array}{l}\text { No. of } \\
\text { studies }\end{array}$ & MIMVR (n) & Sternotomy (n) & $\begin{array}{c}\text { Standard mean } \\
\text { difference } \\
(95 \% \mathrm{CI})\end{array}$ & $P$ - value & $\begin{array}{l}I^{\wedge} 2 \\
(\%)\end{array}$ \\
\hline Cross-clamp time & 6 & 852 & 911 & $1.47(0.52-2.42)$ & 0.003 & 99 \\
\hline CPB time & 6 & 952 & 1,011 & $1.46(0.40-2.51)$ & 0.007 & 99 \\
\hline ICU stay & 2 & 247 & 247 & $-0.77(-1.36-0.17)$ & 0.01 & 88 \\
\hline Length of hospitalization & 4 & 658 & 694 & $-0.24(-0.65-0.18)$ & 0.26 & 92 \\
\hline MIMVR - Minimally In & $\begin{array}{l}\text { Mitral } \\
\text { mic Att }\end{array}$ & $\begin{array}{l}\text { Repair; CI- } \\
\text { PB -Cardio }\end{array}$ & $\begin{array}{l}\text { fidence Interval } \\
\text { onary Bypass; I }\end{array}$ & $\begin{array}{l}\text { Includes Stroke } \\
\text { Intensive Care Un }\end{array}$ & witho & ient \\
\hline
\end{tabular}


Citation: Halim M, AlSayegh M, Umenne CA, Vadithya P, Panicker SV, Israel KA, Halim A. Analyzing and comparing the impacts and outcomes of two different types of surgeries - Minimally Invasive Surgeries (MIS) and Conventional Surgeries (CVS) on patients suffering from Degenerative Mitral Valve Diseases. J Health Care and Research. 2021 Feb 10;2(1):17-32.

\section{Literature Review}

outcomes [38-43], this study revealed that there were no significant statistical differences in clinical outcomes in terms of mortality, stroke, renal failure, wound infections, bleeding, aortic dissection, MI, AF, and readmission within 30 days. There was very lowquality evidence in comparing pain thresholds between the two groups since Cao et al. reviewed only one study that revealed less pain was reported in the MIS group. Besides, both approaches had satisfactory results in that; the incidence of moderate/severe MR decreased from $98.7 \%$ to $0.1 \%$ in MIS and $98.4 \%$ to $0.3 \%$ in the sternotomy group. Table-1 describes the summarized outcomes of the two approaches from the studies investigated.

Qiu et al. (2018) [36] conquered with the findings of Cao et al. in their institutional retrospective review that involved 330 patients who had underwent MVR between January 2011 to January 2017 when they found out that: MIS had longer cross-clamp time, cardiopulmonary bypass time and required less time on ventilation compared to sternotomy. They further agreed with the previous study that there was no significant difference in major complications like stroke and AF; 30-day mortality and morbidity; and long-term survival between the two groups.

However, unlike Cao et al., Qiu et al. found statistical differences in the MIS and sternotomy patients in terms of chest tube drainage that connotes postoperative bleeding which was more in the sternotomy group. Hence, the blood transfusion rate was at $15.7 \%$ compared to sternotomy- 40.6\%. Again the complete sternotomy patients had six sternal wound infections compared to none in the counterpart group. Therefore, they concluded that full sternotomy was an isolated risk factor for the increased need for postoperative blood transfusion, re-operation secondary to bleeding, and longer durations on ventilation support $(\mathrm{p}<0.05)$. These findings are similar to findings in other studies that compared MIMVR with open surgery [39,44-47]. The findings of Qiu et al. (2018) are shown in Fig-3 and Fig-4.

The aim of the multicentre study by Grant S.W. et al. (2018) [38] was to compare the short-term and midterm outcomes between MIS and sternotomy as approaches used in MV surgery. The study analyzed data of 2,404 patients of whom 1,757 had undergone sternotomy and $647 \mathrm{MV}$ repaired through MIS between January 2008 and December 2016 in UK hospitals. Their findings were not very different from the other two previous studies analyzed here; in that MIS group had longer procedural time, lesser need for blood transfusion, and reduced postoperative hospital stay compared to the sternotomy patients. Of note is that re-intervention-free survival at 8 years had no significant statistical differences in the two sides.

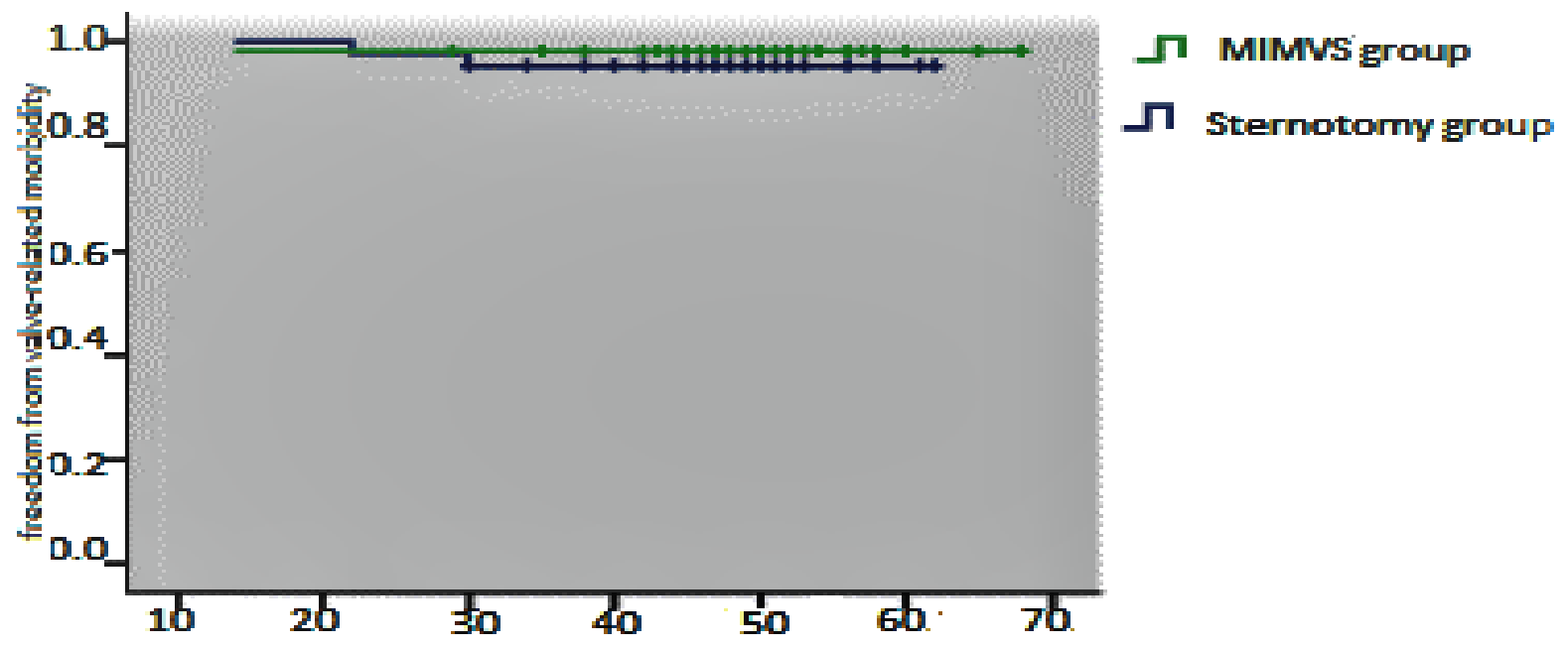

\section{Survival time (Months)}

Fig-3: Kaplan-Meier estimate of freedom from mitral valve-related morbidity of patients with either a right minithoracotomy (green line) or a median sternotomy (blue line) [36] 
Citation: Halim M, AlSayegh M, Umenne CA, Vadithya P, Panicker SV, Israel KA, Halim A. Analyzing and comparing the impacts and outcomes of two different types of surgeries - Minimally Invasive Surgeries (MIS) and Conventional Surgeries (CVS) on patients suffering from Degenerative Mitral Valve Diseases. J Health Care and Research. 2021 Feb 10;2(1):17-32.

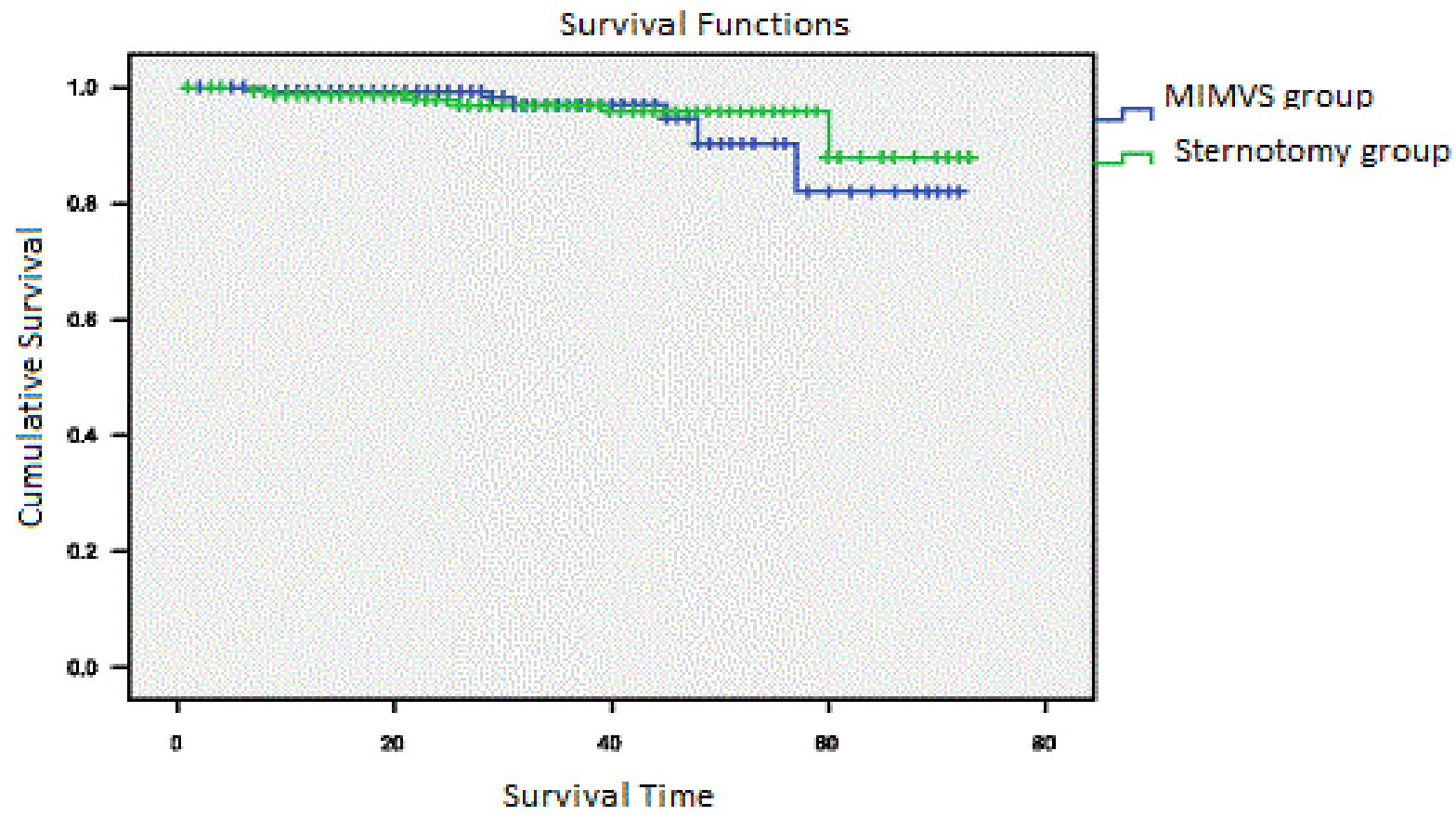

Fig-4: Kaplan-Meier analysis of long term survival for patients after undergoing mitral valve surgeries [36]

\begin{tabular}{|c|c|c|c|}
\hline Operative outcomes & Conventional Sternotomy $n=355$ & Mini-MVR n=355 & $P$-value \\
\hline Concomitant atrial fibrillation procedure & $128(36 \%)$ & $66(18.6 \%)$ & $<0.001$ \\
\hline Mitral repair & $258(72.7 \%)$ & $295(83.1 \%)$ & $<0.001$ \\
\hline Femoral arterial cannulation & $39(11 \%)$ & $331(93 \%)$ & $<0.001$ \\
\hline Cardiopulmonary bypass ${ }^{* *}$ & $112[90,153]$ & $137[116,168]$ & $<0.001$ \\
\hline Cross-clamp time $(\min )^{* *}$ & $75[63,104]$ & $107.5[83,125]$ & $<0.001$ \\
\hline Operative mortality & $4(1.1 \%)$ & $4(1.1 \%)$ & 1 \\
\hline Stroke & $3(0.9 \%)$ & $3(0.9 \%)$ & 1 \\
\hline Renal Failure & $2(0.6 \%)$ & $4(1.1 \%)$ & 0.41 \\
\hline Prolonged ventilation & $15(4.2 \%)$ & $25(7 \%)$ & 0.1 \\
\hline $\begin{array}{l}\text { Total postoperative ventilation time } \\
\text { (hours)** }\end{array}$ & $5.2[3.6,6.7]$ & $4.2[3.2,6.4]$ & 0.003 \\
\hline Deep sternal wound infection & o $(0 \%)$ & o $(0 \%)$ & 1 \\
\hline Reoperation & $12(3.4 \%)$ & $15(4.2 \%)$ & 0.56 \\
\hline Atrial fibrillation & $65(18.3 \%)$ & $55(15 \cdot 5 \%)$ & 0.32 \\
\hline Any postoperative transfusion & $99(28 \%)$ & $41(11.6 \%)$ & $<0.001$ \\
\hline RBC units* & $0.69+/-2.4$ & $0.27+/-1.2$ & 0.004 \\
\hline Blood product units (total)* & $1.41+/-5.4$ & $0.55+/-2.3$ & 0.006 \\
\hline ICU length of stay (hours) ${ }^{* *}$ & $29 \cdot 3[23,70]$ & $24[10.9,47]$ & 0.006 \\
\hline Postoperative length of stay (days) ${ }^{* *}$ & $5[4,8]$ & $4[3,6]$ & $<0.001$ \\
\hline
\end{tabular}


Citation: Halim M, AlSayegh M, Umenne CA, Vadithya P, Panicker SV, Israel KA, Halim A. Analyzing and comparing the impacts and outcomes of two different types of surgeries - Minimally Invasive Surgeries (MIS) and Conventional Surgeries (CVS) on patients suffering from Degenerative Mitral Valve Diseases. J Health Care and Research. 2021 Feb 10;2(1):17-32.

\section{Literature Review}

Minimally Invasive Surgery (MIS) Versus Conventional Surgeries in DMVD Management in terms of Cost of Care:

There are varying critics about MIS adding additional costs without clear benefits over conventional sternotomy in MVR. Downs E.A., et al. (2016) [48] conducted a retrospective study to determine whether MIS provides excellent outcomes without necessarily increasing the costs of MVR in DMVD patients. They extracted regional data of MVR surgeries from 14 cardiac centers from $1^{\text {st }}$ January 2011 to $30^{\text {th }}$ June 2014. After propensity-matching, the study included 355 patients who had undergone MIMVR and a similar number got their MVR through sternotomy while excluding 594. These investigators used Pearson's chi-squared or Fisher's tests and the student's t-test or Wilcoxon rank-sum test to analyze variables and found out that: while MIMVR patients required shorter ICU duration, length in hospital, and fewer blood requirements; this group had the same mortality, morbidity and other complications as sternotomy patients as shown in Table-2.

This is in agreement with prior studies done comparing outcomes in these two groups [49,50]. However, unlike the hypothesis that MIS costs of care are higher than sternotomy, Downs E.A., et al. (2016) findings disputed this as total hospital costs were relatively similar in both groups as shown in Fig-5.

Related observations were noted by Atluri P., et al. (2016) [51], who reviewed a total of 159 patients of whom 68 had been managed by sternotomy and 91 MVR thorough MIMVR. Investigators found out that

\section{Median total hospital cost}

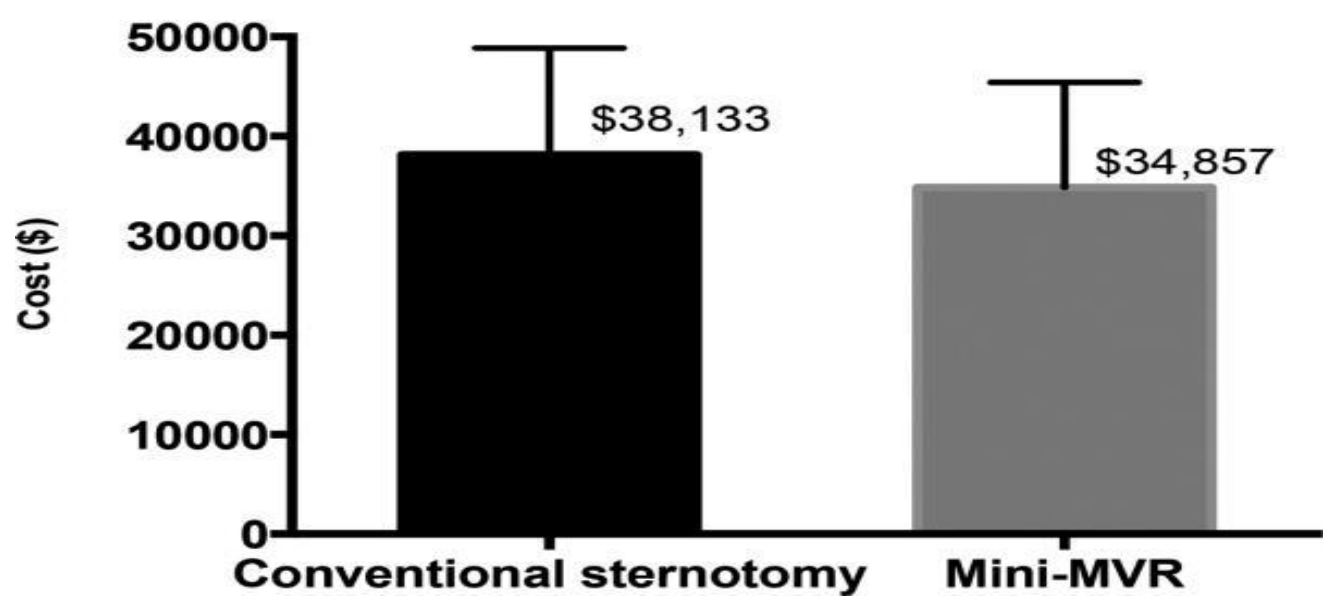

Fig-5: Shows Median total hospital costs for conventional sternotomy versus mini-MVR [48]

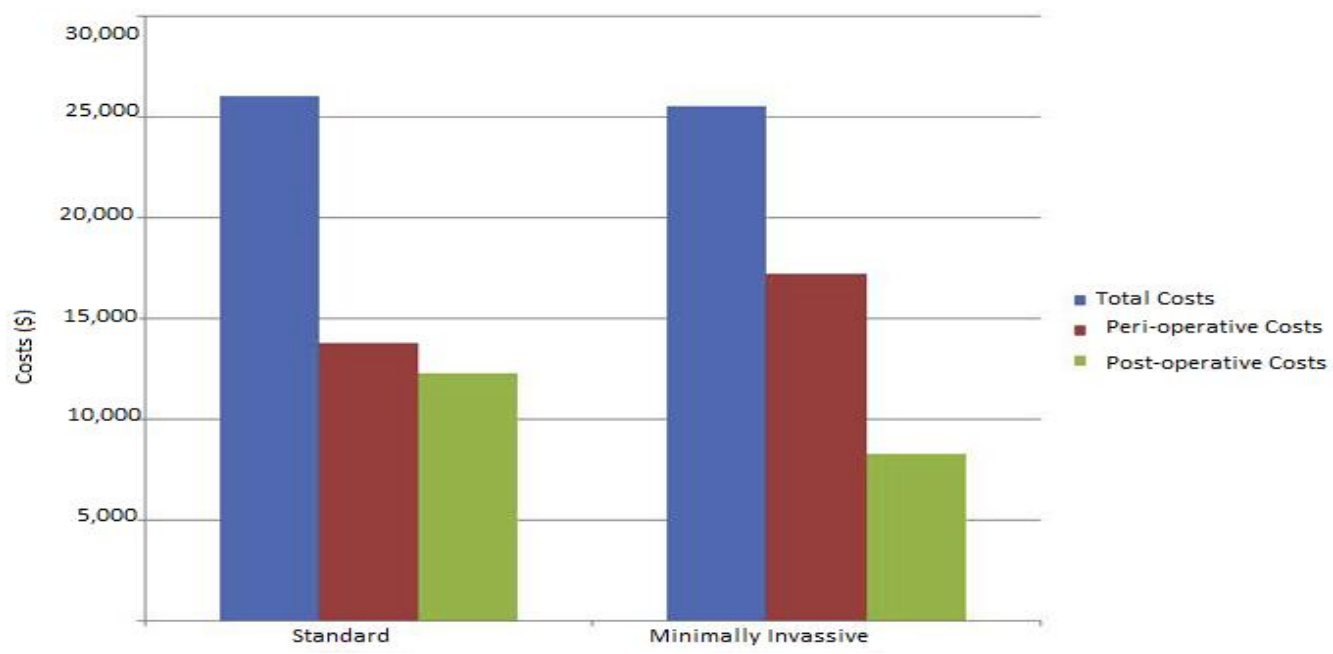

Fig-6: Showing the Cost associated with standard sternotomy and minimally invasive mitral valve repair [51] 
Citation: Halim M, AlSayegh M, Umenne CA, Vadithya P, Panicker SV, Israel KA, Halim A. Analyzing and comparing the impacts and outcomes of two different types of surgeries - Minimally Invasive Surgeries (MIS) and Conventional Surgeries (CVS) on patients suffering from Degenerative Mitral Valve Diseases. J Health Care and Research. 2021 Feb 10;2(1):17-32.

\section{Literature Review}

Table-3: Showing Postoperative outcomes after mitral valve repair, stratified by operative approach [51]

\begin{tabular}{|l|c|c|c|}
\hline \multicolumn{1}{|c|}{ Postoperative Outcomes } & Minimally Invasive & Sternotomy & P-Value \\
\hline Re-exploration for bleeding (\%) & 0 & 0 & $>.999$ \\
\hline Wound infection & 0 & $1(1.5 \%)$ & $>.999$ \\
\hline Stroke & $1(1.1 \%)$ & $1(1.5 \%)$ & $>.999$ \\
\hline Renal failure & 0 & 0 & $>.999$ \\
\hline Aortic dissection & 0 & $6(8.2 \%)$ & 0.999 \\
\hline Ventilatory support>24 h & $5(5.5 \%)$ & $29(42.6 \%)$ & 0.2 \\
\hline Postoperative atrial fibrillation & $26(28.6 \%)$ & $1.5(1-3)$ & 0.05 \\
\hline ICU stay (d, mean and IQR) & $1(1-2)$ & $7(6-7)$ & 0.005 \\
\hline Hospital stay (d, mean and IQR) & $6(5-7)$ & $4(5.5 \%)$ & 0.3 \\
\hline Readmission at 30 d & $3(3.2 \%)$ & 0 & $>.999$ \\
\hline Mortality at 30 d & 0 & 0 & 0.5 \\
\hline
\end{tabular}

Data Represent Number and Percentage PF Patients Unless Otherwise Specified; ICU- Intensive Care Unit; IQRInterquartile Range

\begin{tabular}{|c|c|c|c|}
\hline \multicolumn{4}{|c|}{ Table-4: Showing matched operative outcomes [52] } \\
\hline Operative Outcomes & $\operatorname{Mini}(\mathrm{n}=74)$ & Conventional $(n=74$ & $P$-value \\
\hline Operative mortality & o $(0 \%)$ & $1(1.4 \%)$ & 0.316 \\
\hline Major morbidity & $7(9 \cdot 5 \%)$ & $8(10.8 \%)$ & 0.782 \\
\hline Permanent stroke & $1(1.4 \%)$ & o $(0 \%)$ & 0.316 \\
\hline Cardiac arrest & o $(0 \%)$ & $1(1.4 \%)$ & 0.316 \\
\hline Atrial fibrillation & $15(20.3 \%)$ & $17(23.0 \%)$ & 0.67 \\
\hline Pneumonia & $1(1.4 \%)$ & $2(2.7 \%)$ & 0.564 \\
\hline Prolonged ventilation & $4(5 \cdot 4 \%)$ & $6(8.1 \%)$ & 0.48 \\
\hline Renal failure requiring dialysis & $1(1.4 \%)$ & $1(1.4 \%)$ & 1 \\
\hline Renal failure & $1(1.4 \%)$ & $2(2.7 \%)$ & 0.564 \\
\hline Deep sternal wound infection & o & o & - \\
\hline Transfusion & $8(10.8 \%)$ & $20(27.0 \%)$ & 0.014 \\
\hline Transfusion (pRBC) & $6(8.1 \%)$ & $12(16.2 \%)$ & 0.134 \\
\hline Reoperation for any reason & $4(5 \cdot 4 \%)$ & $4(5 \cdot 4 \%)$ & 1 \\
\hline Reoperation for bleeding & $2(2.7 \%)$ & $1(1.4 \%)$ & 0.564 \\
\hline
\end{tabular}


Citation: Halim M, AlSayegh M, Umenne CA, Vadithya P, Panicker SV, Israel KA, Halim A. Analyzing and comparing the impacts and outcomes of two different types of surgeries - Minimally Invasive Surgeries (MIS) and Conventional Surgeries (CVS) on patients suffering from Degenerative Mitral Valve Diseases. J Health Care and Research. 2021 Feb 10;2(1):17-32.

\section{Literature Review}

although operative costs for MIS are higher compared to sternotomy; there is associated low duration of ICU admissions, hospital stay, and use of blood products which in turn balances costs with sternotomy approach as shown in Fig-6.

The clinical outcomes were relatively equal in both groups. Thus MIS offers the advantage of less time in ICU, intubation, low transfusion frequencies, and shorter hospitalization at a relatively similar cost with good clinical outcomes as a sternotomy as shown in Table-3.

Comparable latest findings were publicized by Hawkins R.B., et al. (2018) [52] when they reviewed MVR surgical records of an institution from 2011 to 2016. They settled on 148 records after propensitymatching using preoperative variables. Then, outcomes were measured against resource utilization and cost; discharge to a facility, and rates of readmissions in the 74 MIMVR patients and 74 sternotomies. They established that there was no significant difference in major morbidity rates, clinical outcomes, postoperative complications, and rate of readmissions as shown in Table-4.

The surgical and implant costs were higher in MIS patients but this was offset by less need of a transfusion, shorter ICU, and hospitalization durations postoperatively compared to sternotomy clients. Therefore, cumulatively, there were insignificant differences in costs in the duo as shown in Fig-7.

These findings tally with other researchers who concluded that MIS incurs similar costs as sternotomy in MVR [53-55].

\section{Cost distribution}

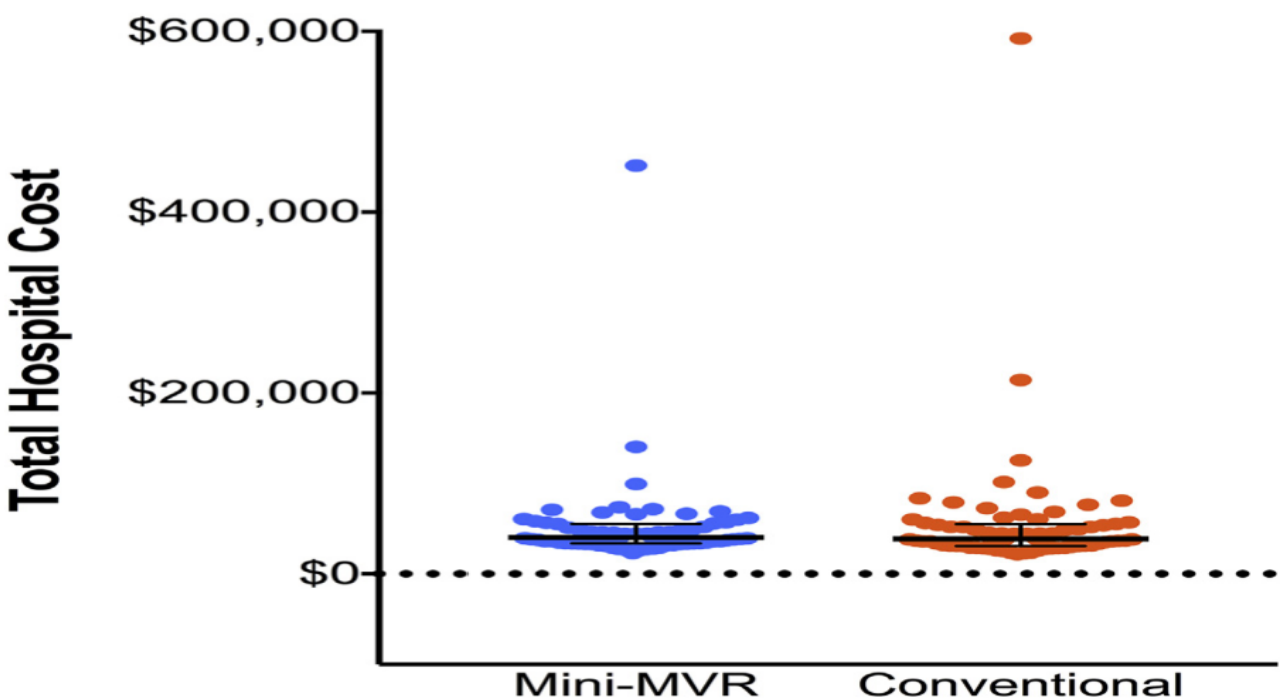

Fig-7: Showing the total hospital costs by approach with median and interquartile range [52]

Minimally Invasive Surgery (MIS) versus

Conventional Surgeries in Reoperations following initial MVR by Sternotomy:

Following MVR by either MIS or sternotomy, $7 \%$ and $11 \%$ of the patients would require re-operation for MVR of MR at 5 and 10 years respectively [56,57]. However, these second operations can be very challenging if the sternotomy approach was used in the initial surgery because of the dense adhesions following scarring and other wound healing complications. Subsequently, there is an increased risk to underlying vascular structures that often lead to increased mortality especially is the surgeon chooses to do sternotomy again in the second operation of the MV [58-6o].

Daemen J.H.T., et al. (2018) [58] carried out a metaanalysis of 6 retrospective studies to quantify the effects of right mini-thoracotomy versus median sternotomy for re-operation of MVR in patients with 
Citation: Halim M, AlSayegh M, Umenne CA, Vadithya P, Panicker SV, Israel KA, Halim A. Analyzing and comparing the impacts and outcomes of two different types of surgeries - Minimally Invasive Surgeries (MIS) and Conventional Surgeries (CVS) on patients suffering from Degenerative Mitral Valve Diseases. J Health Care and Research. 2021 Feb 10;2(1):17-32.

Literature Review

DMVD who had undergone their initial operation with sternotomy approach. Results of this study that included 777 patients indicated reduced mortality rate, length of hospitalization, and rates of re-operation due to bleeding in right minithoracotomy group as compared to median sternotomy patients. Incidence of other complications like stroke had insignificant differences between the two groups. They concluded that MIS is a safer option to median sternotomy in subsequent operations following sternotomy surgery to repair MV. Like findings were also documented by another study [61].

\section{Discussion}

This study aimed at comparing the outcomes and costs of conducting MIS versus conventional open surgery in DMVD patients. MIS has been around for some decades yet despite reported promising results from some institutions, it has not been so much popularised as a preferred surgical approach over the convention [62,63]. Approximately a quarter of MVR surgeries are through MIS yet it isn't because of poor outcomes.

Regardless of the MIS approach used, MIS has been associated with shorter hospitalization and ICU stay, reduced bleeding, early ambulation, early return to activities of daily living, lower blood transfusion requirements, improved cosmetics, and shorter intubation period. Indeed, three studies here that include one meta-analysis and two retrospective observational reviews involving 4,698 subjects revealed so $[20,36,38]$.

Contrary to the proponents that MIS is associated with better clinical outcomes with fewer complications, this literature review revealed otherwise. Conventional MVR and MIMVR have relatively similar satisfactory clinical outcomes and decrease the incidence of severe/moderate MR to below 1\% [20,36].

From the 3 reviews, the incidence of complications such as AF, MI, cardiac arrest, pneumonia, renal failure, major morbidities, mortality rate, and reoperation due to bleeding was analogous in both groups. However, postoperative wound infections and wound healing complications such as scarring were noted in the sternotomy patients [38]. This is logical as MIS incisions are smaller. In the follow-up, it was reported that the incidence of reoperations, short-term (30 days), mid-term and long-term clinical and echocardiographic outcomes had insignificant differences in the two sides [38]. The findings of this study are contrary to the findings of [64-66] that concluded that MIS results in inferior outcomes compared to open MVR.

On the other hand, this study revealed that MIS has associated longer cross-clamp and cardiopulmonary bypass time; requires high expertise, and is only feasible in institutions that have more resources $[20,36]$. This partly explains why it has not been adopted widely. The costs of up-skilling nurses and surgeons; the high cost of video-assistive or robots; additional operation time and space are a major issue that requires more comprehensive review [49,67].

Three studies compared the outcomes and costs of MIS versus sternotomy. All these studies were retrospective observational reviews involving 1,070 subjects. The study revealed that operative costs are high in MIS but associated lower costs of postoperative care compared to sternotomy. Operative costs for MIS were higher due to the duration of the operation, expertise involved, and surgical props and robotics that are expensive equipment. In contrast, during the postoperative period, patients who undergo MIS spent less time in the ICU and overall hospital stay. Besides, ventilator-dependent care duration is less. Because MIS involves less blood loss, there is associated low incidents of blood transfusion, and where blood transfusion is indicated, patients require fewer pints compared to sternotomy $[48,52,62]$.

Cumulatively, the higher operative costs involved in conducting MIS and higher postoperative costs in sternotomy balance the costs. The clinical outcomes were similar in both MIS and sternotomy. Therefore, MIS offers more benefits over conventional surgery while maintaining as good clinical outcomes. However, cost measures did not include the cost of special training of health care workers and major hospital infrastructures like computerized machinery and robots [48]. This can affect the adoption of MIS hence 
Citation: Halim M, AlSayegh M, Umenne CA, Vadithya P, Panicker SV, Israel KA, Halim A. Analyzing and comparing the impacts and outcomes of two different types of surgeries - Minimally Invasive Surgeries (MIS) and Conventional Surgeries (CVS) on patients suffering from Degenerative Mitral Valve Diseases. J Health Care and Research. 2021 Feb 10;2(1):17-32.

Literature Review

a call for comparable studies considering all costs associated with MIS for facilities.

Recurrence of MR following MVR is the most common problem with about a $10^{\text {th }}$ of the patients requiring reoperations [56]. This study reports that in cases where the initial surgery was sternotomy, then re-operation using the same approach possess challenges to surgeons and increases risks for vascular damages because of dense adhesions and scarring from previous scar [62]. An alternative to this is the use of MIS in pre-operating DMVD patients previously operated using sternotomy as it offers good clinical outcomes as revealed by this study $[58,61]$. Given that future re-operations are inevitable in some patients with DMVD, this study recommends the use of MIS during initial and subsequent MVR in these patients.

However, the generativity of the findings in this study should be done carefully because of the study limitations. First, all the studies but for one RCT in one of the meta-analysis studies used were retrospective observational reviews prone to selection bias. Even though propensity- matching analysis was used in some studies, generally, it was challenging to attain uniform patient characteristics in the two arms. Therefore, Randomized Clinical Trials (RCT) are called for. Second, the small sample size (4,698 subjects) used in this study can affect its application in a general population hence recommendations for comparable studies with a huge sample. Also, the definition of terms varied among the studies used. For example, stroke in Cao et al. (2013) involved a cardiovascular accident and transient ischemic attacks while stroke was defined as a cardiovascular accident in Qiu et al. (2018) which might have affected the study findings.

\section{Meta-Analysis Table}

Table-5 is constructed to highlight the main contents of this literature review based on a thorough

Table-5: Constructed to highlight the main contents of this literature review based on a thorough analysis of all the primary research, studies and data involved

\begin{tabular}{|c|c|c|c|c|}
\hline Author & Title & Design & $\begin{array}{c}\text { Sample } \\
\text { size }\end{array}$ & Relevance to the Topic \\
\hline $\begin{array}{l}\text { Cao et al. } \\
(2013)[20]\end{array}$ & $\begin{array}{l}\text { A meta-analysis of } \\
\text { minimally invasive } \\
\text { mitral valve repair } \\
\text { for patients with } \\
\text { degenerative mitral } \\
\text { valve disease }\end{array}$ & $\begin{array}{l}\text { A meta-analysis of } \\
7 \text { studies (1-RCT } \\
\text { and } 6 \\
\text { retrospective } \\
\text { observational } \\
\text { reviews }\end{array}$ & 1,940 & $\begin{array}{l}\text { The study compared clinical outcomes and } \\
\text { echocardiographic outcomes between MIS and } \\
\text { conventional open surgery. The study } \\
\text { concluded that MIS requires more cross-clamp } \\
\text { and cardiopulmonary bypass time. MIS had the } \\
\text { advantage of shorter ICU and intubation } \\
\text { duration but no effect on overall hospitalization } \\
\text { duration. The clinical and echocardiographic } \\
\text { outcomes were similar in MIS and sternotomy. } \\
\text { There was weak evidence on the measurement } \\
\text { of pain threshold in this study. }\end{array}$ \\
\hline $\begin{array}{l}\text { Qiu et al. } \\
\text { (2018) [36] }\end{array}$ & $\begin{array}{l}\text { Does full } \\
\text { sternotomy have a } \\
\text { more significant } \\
\text { impact than the } \\
\text { cardiopulmonary } \\
\text { bypass time in } \\
\text { patients of mitral } \\
\text { valve surgery? }\end{array}$ & $\begin{array}{l}\text { Retrospective } \\
\text { observational } \\
\text { review }\end{array}$ & 330 & $\begin{array}{l}\text { The study compared MIS with sternotomy in } \\
\text { terms of cross-clamp time, cardiopulmonary } \\
\text { bypass time, bleeding, ventilation time and } \\
\text { postoperative complications. Cardiopulmonary } \\
\text { bypass and cross-clamp time were more in MIS. } \\
\text { MIS group had less ventilation duration, fewer } \\
\text { wound infections, reduced bleeding and need } \\
\text { for blood transfusion compares to sternotomy. }\end{array}$ \\
\hline $\begin{array}{l}\text { Grant S.W. } \\
\text { et al. (2018) } \\
{[38]}\end{array}$ & $\begin{array}{l}\text { Propensity-matched } \\
\text { analysis of } \\
\text { minimally invasive } \\
\text { approach versus } \\
\text { sternotomy for } \\
\text { mitral valve } \\
\text { surgery. }\end{array}$ & $\begin{array}{l}\text { Retrospective } \\
\text { observational } \\
\text { review }\end{array}$ & 2,404 & $\begin{array}{l}\text { Short-term and mid-term outcomes of MIS } \\
\text { versus sternotomy were compared here. MIS } \\
\text { group had longer operation time, reduced blood } \\
\text { need and shorter postoperative hospital stay. } \\
\text { Short-term and mid-term clinical outcomes had } \\
\text { insignificant differences in both groups. }\end{array}$ \\
\hline
\end{tabular}


Citation: Halim M, AlSayegh M, Umenne CA, Vadithya P, Panicker SV, Israel KA, Halim A. Analyzing and comparing the impacts and outcomes of two different types of surgeries - Minimally Invasive Surgeries (MIS) and Conventional Surgeries (CVS) on patients suffering from Degenerative Mitral Valve Diseases. J Health Care and Research. 2021 Feb 10;2(1):17-32.

\section{Literature Review}

\begin{tabular}{|c|c|c|c|c|}
\hline $\begin{array}{l}\text { Downs E.A., } \\
\text { et al. (2016) } \\
\text { [48] }\end{array}$ & $\begin{array}{l}\text { Minimally invasive } \\
\text { mitral valve surgery } \\
\text { provides excellent } \\
\text { outcomes without } \\
\text { increased cost: A } \\
\text { multi-institutional } \\
\text { analysis. }\end{array}$ & $\begin{array}{l}\text { Retrospective } \\
\text { observational } \\
\text { review }\end{array}$ & 710 & $\begin{array}{l}\text { Compared the clinical outcomes and costs } \\
\text { between MIS and sternotomy. MIS patients had } \\
\text { shorter ICU admission and hospitalization that } \\
\text { sternotomy. The clinical outcomes, } \\
\text { complications and costs had insignificant } \\
\text { differences between the groups. }\end{array}$ \\
\hline $\begin{array}{l}\text { Atluri P., et } \\
\text { al. (2016) } \\
\text { [51] }\end{array}$ & $\begin{array}{l}\text { Minimally invasive } \\
\text { mitral valve surgery } \\
\text { is associated with } \\
\text { equivalent cost and } \\
\text { shorter hospital } \\
\text { stay when } \\
\text { compared to } \\
\text { traditional } \\
\text { sternotomy. }\end{array}$ & $\begin{array}{l}\text { Retrospective } \\
\text { observational } \\
\text { review }\end{array}$ & 159 & $\begin{array}{l}\text { The study compared operative and } \\
\text { postoperative costs of MIS compared to } \\
\text { sternotomy. It revealed that although MIS } \\
\text { operative costs are higher, this is balanced by } \\
\text { shorter duration in ICU, shorter hospitalization } \\
\text { periods and less need for blood products. The } \\
\text { clinical outcomes and complications had no } \\
\text { significant variations between MIS and } \\
\text { sternotomy. }\end{array}$ \\
\hline \multirow{2}{*}{$\begin{array}{l}\text { Hawkins } \\
\text { R.B., et al. } \\
\text { (2018) [52] }\end{array}$} & \multirow{2}{*}{$\begin{array}{l}\text { Minimally invasive } \\
\text { mitral valve surgery } \\
\text { is associated with } \\
\text { excellent resource } \\
\text { utilization, cost and } \\
\text { outcomes. }\end{array}$} & \multirow{2}{*}{$\begin{array}{l}\text { Retrospective } \\
\text { observational } \\
\text { review }\end{array}$} & \multirow{2}{*}{148} & $\begin{array}{l}\text { They compared mortality and morbidity rates, } \\
\text { clinical outcomes, other complications and } \\
\text { resource utilization between MIS and } \\
\text { sternotomy in mitral valve disease patients. }\end{array}$ \\
\hline & & & & $\begin{array}{l}\text { They concluded that there were no significant } \\
\text { variations in clinical outcomes, mortality and } \\
\text { morbidity rates, the incidence of complications } \\
\text { and resource utilization between MIS and } \\
\text { sternotomy. }\end{array}$ \\
\hline $\begin{array}{l}\text { Daemen } \\
\text { J.H.T., et al. } \\
(2018) \text { [58] }\end{array}$ & $\begin{array}{l}\text { Right } \\
\text { minithoracotomy } \\
\text { versus median } \\
\text { sternotomy for re- } \\
\text { operative mitral } \\
\text { valve surgery: A } \\
\text { systematic review } \\
\text { and a meta- } \\
\text { analysis. }\end{array}$ & $\begin{array}{l}\text { A systematic } \\
\text { meta-analysis of } 6 \\
\text { studies (all } \\
\text { Retrospective } \\
\text { observational } \\
\text { reviews) }\end{array}$ & 777 & $\begin{array}{l}\text { The study quantified the effects of using right } \\
\text { minithoracotomy versus sternotomy on re- } \\
\text { operating mitral valve disease patients whose } \\
\text { initial surgery was through a sternotomy } \\
\text { approach. Reduced mortality rate, length of } \\
\text { hospitalization and rates of re-operation due to } \\
\text { bleeding was observed in minithoracotomy } \\
\text { patients. Incidence of other complications like } \\
\text { stroke and AF were relatively similar in both } \\
\text { approaches. }\end{array}$ \\
\hline
\end{tabular}

analysis of all the primary research, studies, and data involved.

\section{Conclusion and Recommendations}

This study compared the outcomes and costs of MIS versus convention surgery in patients with DMVD undergoing MVR. The study revealed that MIS has similar outcomes to sternotomy but with an added advantage of reduced bleeding, lower blood transfusion rates, reduced hospital and ICU stay, early ambulation and return to activities of daily living, fewer wound infections, and decreased need for prolonged intubation. Contrariwise, MIS has a long cross-clamp and cardiopulmonary bypass time and thus overall operation duration is longer. The echocardiographic outcomes and costs involved in both surgeries are relatively equal. Therefore, the study recommends MIS over conventional surgery in initial and subsequent MVR in patients with DMVD. A more in-depth comprehensive cost analysis between MIS and sternotomy is encouraged before the adoption of MIS on wide scales.

\section{Acknowledgement}

Michael Halim, Mariam AlSayegh, Chidinma Angela Umenne, Priyanka Vadithya, and Swetha Vishnu Panicker all contributed equally to the research and writing of this article.

\section{Conflict of Interest}

The author has read and approved the final version of the manuscript. The author has no conflicts of 
Citation: Halim M, AlSayegh M, Umenne CA, Vadithya P, Panicker SV, Israel KA, Halim A. Analyzing and comparing the impacts and outcomes of two different types of surgeries - Minimally Invasive Surgeries (MIS) and Conventional Surgeries (CVS) on patients suffering from Degenerative Mitral Valve Diseases. J Health Care and Research. 2021 Feb 10;2(1):17-32.

Literature Review

interest to declare.

\section{References}

[1] Delling FN, Vasan RS. Epidemiology and pathophysiology of mitral valve prolapse: new insights into disease progression, genetics, and molecular basis. Circulation. 2014 May 27;129(21):2158-70. [PMID: 24867995]

[2] Borgarelli M, Buchanan JW. Historical review, epidemiology and natural history of degenerative mitral valve disease. J Vet Cardiol. 2012 Mar;14(1):93101. [PMID: 22386588]

[3] Cohn LH, Adams DH. Cardiac Surgery in the Adult. 5th ed. New York: Mc Graw Hill Education; 2018. 792$93 \mathrm{pp}$.

[4] Neto FL, Marques LC, Aiello VD. Myxomatous degeneration of the mitral valve. Autops Case Rep. 2018 Nov 30;8(4):e2018058. [PMID: 30775329]

[5] UCSH Health. HEART \& VASCULAR: Mitral Valve Disorders. University of California San Francisco; 2020.

[6] Adams DH, Anyanwu AC, Rahmanian PB, Filsoufi F. Current concepts in mitral valve repair for degenerative disease. Heart Fail Rev. 2006 Sep;11(3):241-57. [PMID: 17041764]

[7] Sayeed R. Mitral valve disease when should we call in the cardiac surgeon. E-Journal Cardiol Pract. 2018;16:28

[8] Uchicago Medicine. Traditional Open-Chest Coronary Artery Bypass Surgery. USA: At the forefront UChicago Medicine; 2020. Available from:

https://www.uchicagomedicine.org/conditionsservices/heart-vascular/coronary-arterydisease/coronary-artery-surgery/traditional-openbypass

[9] Mohty D, Orszulak TA, Schaff HV, Avierinos JF, Tajik JA, Enriquez-Sarano M. Very long-term survival and durability of mitral valve repair for mitral valve prolapse. Circulation. 2001 Sep 18;104 (12 Suppl 1):I1-I7. [PMID: 11568020]

[10] Ullah W, Sattar Y, Mukhtar M, Abdullah HM, Figueredo VM, Haas DC, Fischman DL, Chadi Alraies M. Outcomes of open mitral valve replacement versus Transcatheter mitral valve repair; insight from the National Inpatient Sample Database. Int J Cardiol Heart Vasc. 2020 May 28;28:100540. [PMID: 32490147]
[11] Liu J, Sidiropoulos A, Konertz W. Minimally invasive aortic valve replacement (AVR) compared to standard AVR. Eur J Cardiothorac Surg. 1999 Nov;16 Suppl 2:S80-83. [PMID: 10613563]

[12] Casselman FP, Van Slycke S, Wellens F, De Geest R, Degrieck I, Vermeulen Y, Van Praet F, Vanermen H. From classical sternotomy to truly endoscopic mitral valve surgery: a step by step procedure. Heart Lung Circ. 2003;12(3):172-77. [PMID: 16352128]

[13] de Vaumas C, Philip I, Daccache G, Depoix JP, Lecharny JB, Enguerand D, Desmonts JM. Comparison of minithoracotomy and conventional sternotomy approaches for valve surgery. J Cardiothorac Vasc Anesth. 2003 Jun;17(3):325-28. [PMID: 12827580]

[14] Gaudiani VA, Grunkemeier GL, Castro LJ, Fisher $\mathrm{AL}, \mathrm{Wu} \mathrm{Y}$. Mitral valve operations through standard and smaller incisions. Heart Surg Forum. 2004 Jan 1;7(4):E337-42. [PMID: 15454389]

[15] Suri RM, Schaff HV, Meyer SR, Hargrove WC 3rd. Thoracoscopic versus open mitral valve repair: a propensity score analysis of early outcomes. Ann Thorac Surg. 2009 Oct;88(4):1185-90. [PMID: 19766804]

[16] Dumont E, Gillinov AM, Blackstone EH, Sabik JF 3rd, Svensson LG, Mihaljevic T, Houghtaling PL, Lytle BW. Reoperation after mitral valve repair for degenerative disease. Ann Thorac Surg. 2007 Aug;84(2):444-50; discussion 450. [PMID: 17643613]

[17] Svensson LG, Gillinov AM, Blackstone EH, Houghtaling PL, Kim KH, Pettersson GB, Smedira NG, Banbury MK, Lytle BW. Does right thoracotomy increase the risk of mitral valve reoperation? J Thorac Cardiovasc Surg. 2007 Sep;134(3):677-82. [PMID: 17723817]

[18] Xu RB, Rahnavardi M, Nadal M, Viana F, Stuklis RG, Worthington M, Edwards J. Beating heart minimally invasive mitral valve surgery in patients with previous sternotomy: the operative technique and early outcomes. Open Heart. 2018 Jan 20;5(1):eooo749. [PMID: 29387434]

[19] McKeown LA. STS Data: Mitral Valve Cases Are Fastest-Growing CV Surgical Intervention in North America. tctmd. $2018 \mathrm{Jul}$ 25. Available from: https://www.tctmd.com/news/sts-data-mitral-valvecases-are-fastest-growing-cv-surgical-interventionnorth-america 
Citation: Halim M, AlSayegh M, Umenne CA, Vadithya P, Panicker SV, Israel KA, Halim A. Analyzing and comparing the impacts and outcomes of two different types of surgeries - Minimally Invasive Surgeries (MIS) and Conventional Surgeries (CVS) on patients suffering from Degenerative Mitral Valve Diseases. J Health Care and Research. 2021 Feb 10;2(1):17-32.

Literature Review

[20] Cao C, Gupta S, Chandrakumar D, Nienaber TA, Indraratna P, Ang SC, Phan K, Yan TD. A meta-analysis of minimally invasive versus conventional mitral valve repair for patients with degenerative mitral disease. Ann Cardiothorac Surg. 2013 Nov;2(6):693-703. [PMID: 24349970]

[21] Okamoto K. Minimally invasive cardiac surgery in Japan: history and current status. Gen Thorac Cardiovasc Surg. 2018 Sep;66(9):504-508. [PMID: 30019253]

[22] Pope NH, Ailawadi G. Minimally invasive valve surgery. J Cardiovasc Transl Res. 2014 Jun;7(4):38794. [PMID: 24797148]

[23] Cohn LH, Soltesz EG. The evolution of mitral valve surgery: 1902-2002. Am Heart Hosp J. 2003 Winter;1(1):40-46. Erratum in: Am Heart Hosp J. 2003 Spring;1(2):182. [PMID: 15785175]

[24] Vo AT, Nguyen DH, Van Hoang S, Le KM, Nguyen TT, Nguyen VL, Nguyen BH, Truong BQ. Learning curve in minimally invasive mitral valve surgery: a single-center experience. J Cardiothorac Surg. 2019 Dec 5;14(1):213. [PMID: 31806039]

[25] Shcherbatyuk KV, Komarov RN, Pidanov OY. Mini-torakotomiia $\mathrm{v}$ khirurgii mitral'nogo klapana [Right thoracotomy approach for minimally invasive mitral valve surgery]. Khirurgiia (Mosk). 2019;(12):121-25. Russian. [PMID: 31825352]

[26] Mayo Clinic. Minimally invasive heart surgery. Mayo Clinic; 2020. Available from:

https://www.mayoclinic.org/tests-

procedures/minimally-invasive-heart-

surgery/about/pac-20384895

[27] Marin Cuartas M, Javadikasgari H, Pfannmueller B, Seeburger J, Gillinov AM, Suri RM, Borger MA. Mitral valve repair: Robotic and other minimally invasive approaches. Prog Cardiovasc Dis. 2017 NovDec;6o(3):394-404. [PMID: 29128572]

[28] Maselli D, Pizio R, Borelli G, Musumeci F. Endovascular balloon versus transthoracic aortic clamping for minimally invasive mitral valve surgery: impact on cerebral microemboli. Interact Cardiovasc Thorac Surg. 2006 Apr;5(2):183-86. [PMID: 17670543]

[29] Modi P, Hassan A, Chitwood WR Jr. Minimally invasive mitral valve surgery: a systematic review and meta-analysis. Eur J Cardiothorac Surg. 2008 Nov;34(5):943-52. [PMID: 18829343]
[30] Gleneagles Hospitals. Minimally Invasive Cardiac Surgery. Singapore: Gleneagles Hospitals; 2020.

[31] Andrade WL, Amoretti JR. Minimally invasive surgical valve repair. Heart Surg Forum. 2010 Jun;13(3):E165-67. [PMID: 20534417]

[32] Wang D, Wang Q, Yang X, Wu Q, Li Q. Mitral valve replacement through a minimal right vertical infra-axillary thoracotomy versus standard median sternotomy. Ann Thorac Surg. 2009 Mar;87(3):704708. [PMID: 19231374]

[33] Jiang Q, Wang Z, Guo J, Yu T, Zhang X, Hu S. Retrospective Comparison of Endoscopic Versus Open Procedure for Mitral Valve Disease. J Invest Surg. 2020 Feb 16:1-7. [PMID: 32064986]

[34] Fan H, Xi Ming Q, Wei Min Z, Huai Dong C. Comparison of Totally Thoracoscopic and Traditional Sternotomy Approaches for Mitral Valve Replacement. Heart Surg Forum. 2019 Jul 26;22(4):E310-14. [PMID: 31398099]

[35] Cheng DC, Martin J, Lal A, Diegeler A, Folliguet TA, Nifong LW, Perier P, Raanani E, Smith JM, Seeburger J, Falk V. Minimally invasive versus conventional open mitral valve surgery: a metaanalysis and systematic review. Innovations (Phila). 2011 Mar;6(2):84-103. [PMID: 22437892]

[36] Qiu Z, Chen X, Xu Y, Huang F, Xiao L, Yang T, Yin L. Does full sternotomy have more significant impact than the cardiopulmonary bypass time in patients of mitral valve surgery? J Cardiothorac Surg. 2018 Apr 14;13(1):29. [PMID: 29653554]

[37] Sharony R, Grossi EA, Saunders PC, Schwartz CF, Ursomanno P, Ribakove GH, Galloway AC, Colvin SB. Minimally invasive reoperative isolated valve surgery: early and mid-term results. J Card Surg. 2006 MayJun;21(3):240-44. [PMID: 16684050]

[38] Grant SW, Hickey GL, Modi P, Hunter S, Akowuah E, Zacharias J. Propensity-matched analysis of minimally invasive approach versus sternotomy for mitral valve surgery. Heart. 2019 May;105(10):783-89. [PMID: 3054176o]

[39] Huang HL, Yan Q, Xie XJ, Zhou K, He BC, Yang L. Early outcomes of mitral valvuloplasty by minimally invasive surgery or sternotomy. Asian Cardiovasc Thorac Ann. 2020 Sep;28(7):398-403. [PMID: 32122150]

[40] Lange R, Voss B, Kehl V, Mazzitelli D, TassaniPrell P, Günther T. Right Minithoracotomy Versus Full 
Citation: Halim M, AlSayegh M, Umenne CA, Vadithya P, Panicker SV, Israel KA, Halim A. Analyzing and comparing the impacts and outcomes of two different types of surgeries - Minimally Invasive Surgeries (MIS) and Conventional Surgeries (CVS) on patients suffering from Degenerative Mitral Valve Diseases. J Health Care and Research. 2021 Feb 10;2(1):17-32.

Literature Review

Sternotomy for Mitral Valve Repair: A Propensity Matched Comparison. Ann Thorac Surg. 2017 Feb;103(2):573-79. [PMID: 27623272]

[41] Gulbins H, Pritisanac A, Hannekum A. Minimally invasive heart valve surgery: already established in clinical routine? Expert Rev Cardiovasc Ther. 2004 Nov;2(6):837-43. [PMID: 15500429]

[42] Raja SG, Navaratnarajah M. Impact of minimal access valve surgery on clinical outcomes: current best available evidence. J Card Surg. 20o9 Jan-Feb;24(1):7379. [PMID: 19120680]

[43] Galloway AC, Schwartz CF, Ribakove GH, Crooke GA, Gogoladze G, Ursomanno P, Mirabella M, Culliford AT, Grossi EA. A decade of minimally invasive mitral repair: long-term outcomes. Ann Thorac Surg. 2009 Oct;88(4):1180-84. [PMID: 19766803]

[44] Mkalaluh S, Szczechowicz M, Dib B, Sabashnikov A, Szabo G, Karck M, Weymann A. Early and long-term results of minimally invasive mitral valve surgery through a right mini-thoracotomy approach: a retrospective propensity-score matched analysis. PeerJ. 2018 May 28;6:e4810. [PMID: 29868261]

[45] Sündermann SH, Czerny M, Falk V. Open vs. Minimally Invasive Mitral Valve Surgery: Surgical Technique, Indications and Results. Cardiovasc Eng Technol. 2015 Jun;6(2):16o-66. [PMID: 26577232]

[46] Nishi H, Miyata H, Motomura N, Toda K, Miyagawa S, Sawa Y, Takamoto S. Propensity-matched analysis of minimally invasive mitral valve repair using a nationwide surgical database. Surg Today. 2015 Sep;45(9):1144-52. [PMID: 26112649]

[47] Al Otaibi A, Gupta S, Belley-Cote EP, Alsagheir A, Spence J, Parry D, Whitlock RP. Mini-thoracotomy vs. conventional sternotomy mitral valve surgery: a systematic review and meta-analysis. J Cardiovasc Surg (Torino). 2017 Jun;58(3):489-96. [PMID: 27588617]

[48] Downs EA, Johnston LE, LaPar DJ, Ghanta RK, Kron IL, Speir AM, Fonner CE, Kern JA, Ailawadi G. Minimally Invasive Mitral Valve Surgery Provides Excellent Outcomes Without Increased Cost: A MultiInstitutional Analysis. Ann Thorac Surg. 2016 Jul;102(1):14-21. [PMID: 27041453]

[49] Iribarne A, Russo MJ, Easterwood R, Hong KN, Yang J, Cheema FH, Smith CR, Argenziano M. Minimally invasive versus sternotomy approach for mitral valve surgery: a propensity analysis. Ann
Thorac Surg. 2010 Nov;9o(5):1471-77; discussion 147778. [PMID: 20971243]

[50] Gillinov AM, Cosgrove DM. Minimally invasive mitral valve surgery: mini-sternotomy with extended transseptal approach. Semin Thorac Cardiovasc Surg. 1999 Jul;11(3):206-11. [PMID: 10451251]

[51] Atluri P, Stetson RL, Hung G, Gaffey AC, Szeto WY, Acker MA, Hargrove WC. Minimally invasive mitral valve surgery is associated with equivalent cost and shorter hospital stay when compared with traditional sternotomy. J Thorac Cardiovasc Surg. 2016 Feb;151(2):385-88. [PMID: 26432722]

[52] Hawkins RB, Mehaffey JH, Kessel SM, Dahl JJ, Kron IL, Kern JA, Yarboro LT, Ailawadi G. Minimally invasive mitral valve surgery is associated with excellent resource utilization, cost, and outcomes. J Thorac Cardiovasc Surg. 2018 Aug;156(2):611-16.e3. [PMID: 29709359]

[53] Iribarne A, Easterwood R, Russo MJ, Wang YC, Yang J, Hong KN, Smith CR, Argenziano M. A minimally invasive approach is more cost-effective than a traditional sternotomy approach for mitral valve surgery. J Thorac Cardiovasc Surg. 2011 Dec;142(6):1507-14. [PMID: 21665228]

[54] Cohn LH, Adams DH, Couper GS, Bichell DP, Rosborough DM, Sears SP, Aranki SF. Minimally invasive cardiac valve surgery improves patient satisfaction while reducing costs of cardiac valve replacement and repair. Ann Surg. 1997 Oct;226(4):421-26; discussion 427-28. [PMID: 9351710]

[55] Morgan JA, Thornton BA, Peacock JC, Hollingsworth KW, Smith CR, Oz MC, Argenziano M. Does robotic technology make minimally invasive cardiac surgery too expensive? A hospital cost analysis of robotic and conventional techniques. J Card Surg. 2005 May-Jun;20(3):246-51. [PMID: 15854086]

[56] Flameng W, Herijgers P, Bogaerts K. Recurrence of mitral valve regurgitation after mitral valve repair in degenerative valve disease. Circulation. 2003 Apr 1;107(12):16o9-13. [PMID: 12668494]

[57] Noack T, Kiefer P, Vivell N, Sieg F, Marin-Cuartas M, Leontyev S, Holzhey DM, Garbade J, Pfannmueller B, Davierwala P, Misfeld M, Seeburger J, Borger MA. Annuloplasty ring dehiscence after mitral valve repair: incidence, localization and reoperation. Eur J Cardiothorac Surg. 2020 Feb 1;57(2):300-307. 
Citation: Halim M, AlSayegh M, Umenne CA, Vadithya P, Panicker SV, Israel KA, Halim A. Analyzing and comparing the impacts and outcomes of two different types of surgeries - Minimally Invasive Surgeries (MIS) and Conventional Surgeries (CVS) on patients suffering from Degenerative Mitral Valve Diseases. J Health Care and Research. 2021 Feb 10;2(1):17-32.

\section{Literature Review}

\section{[PMID: 31369069]}

[58] Daemen JHT, Heuts S, Olsthoorn JR, Maessen JG, Sardari Nia P. Right minithoracotomy versus median sternotomy for reoperative mitral valve surgery: a systematic review and meta-analysis of observational studies. Eur J Cardiothorac Surg. 2018 Nov 1;54(5):817-25. [PMID: 29688301]

[59] Park CB, Suri RM, Burkhart HM, Greason KL, Dearani JA, Schaff HV, Sundt TM 3rd. Identifying patients at particular risk of injury during repeat sternotomy: analysis of 2555 cardiac reoperations. J Thorac Cardiovasc Surg. 2010 Nov;140(5):1028-35. [PMID: 20951254]

[6o] Potter DD, Sundt TM 3rd, Zehr KJ, Dearani JA, Daly RC, Mullany CJ, McGregor CG, Puga FJ, Schaff HV, Orszulak TA. Operative risk of reoperative aortic valve replacement. J Thorac Cardiovasc Surg. 2005 Jan;129(1):94-103. [PMID: 15632830]

[61] Murzi M, Miceli A, Di Stefano G, Cerillo AG, Farneti P, Solinas M, Glauber M. Minimally invasive right thoracotomy approach for mitral valve surgery in patients with previous sternotomy: a single institution experience with 173 patients. J Thorac Cardiovasc Surg. 2014 Dec;148(6):2763-68. [PMID: 25224550]

[62] Atluri P, Stetson RL, Hung G, Gaffey AC, Szeto WY, Acker MA, Hargrove WC. Minimally invasive mitral valve surgery is associated with equivalent cost and shorter hospital stay when compared with traditional sternotomy. J Thorac Cardiovasc Surg. 2016 Feb;151(2):385-88. [PMID: 26432722]
[63] Gammie JS, Zhao Y, Peterson ED, O'Brien SM, Rankin JS, Griffith BP. J. Maxwell Chamberlain Memorial Paper for adult cardiac surgery. Lessinvasive mitral valve operations: trends and outcomes from the Society of Thoracic Surgeons Adult Cardiac Surgery Database. Ann Thorac Surg. 2010 Nov;90(5):1401-8, 1410.e1; discussion 1408-10. [PMID: 20971230]

[64] Farhat F, Metton O, Jegaden O. Benefits and complications of total sternotomy and ministernotomy in cardiac surgery. Surg Technol Int. 2004;13:199-205. [PMID: 15744691]

[65] Missault S, Causenbroeck JV, Vandewiele K, Czapla J, Philipsen T, François K, Bové T. Analysis of clinical outcome and postoperative organ function effects in a propensity-matched comparison between conventional and minimally invasive mitral valve surgery. J Card Surg. 2020 Sep 9. [PMID: 32906198]

[66] Kobayashi J, Sasako Y, Minatoya K, Kitamura S. [Indications for and limitations of minimally invasive cardiac surgery with the lower ministernotomy approach]. Nihon Geka Gakkai Zasshi. 1998 Dec;99(12):831-36. Japanese. [PMID: 10063495]

[67] Moscarelli M, Fattouch K, Gaudino M, Nasso G, Paparella D, Punjabi P, Athanasiou T, Benedetto U, Angelini GD, Santarpino G, Speziale G. Minimal Access Versus Sternotomy for Complex Mitral Valve Repair: A Meta-Analysis. Ann Thorac Surg. 2020 Mar;109(3):737-44. [PMID: 31479637]

Keywords: Degenerative Mitral Valve Disease, Mitral Valve Prolapse Syndrome, Minimally Invasive Surgical Procedures, Mitral Valve Repair, Mini-Thoracotomy, Open Surgery, Open-Heart Surgery, Sternotomy, Conventional 